Journal of Agriculture and Food Sciences

Volume 11 Number 1, A pril 2013 pp. 32-43.

P. C. Ike

\title{
EXAMINATION OF POVERTY GENDER GAP AMONG HOUSEHOLDS IN UKWUANI LOCAL GOVERNMENT AREA OF DELTA STATE, NIGERIA
}

\author{
P. C. IKE \\ Department of Agricultural Economics and Extension, Delta state university, Asaba Campus, \\ Nigeria \\ email: ikepeecee@yahoo.com
}

\begin{abstract}
This study was carried out to estimate poverty gap among female and male headed farm families in Ukwani local government area (LGA) of Delta State, Nigeria. Simple random sampling technique was used to select seven out of the 10 communities that make up the LGA. From each of these selected communities 10 respondents were selected from a list of farm families drawn with assistance of extension officers covering the area. This gave a total sample size of 70 respondents. The study was conducted in 2012. Various methods were employed in analyzing the data, including descriptive statistical tools and inferential statistics such as t-test and ordinary least square regression analysis. Results of the study indicate that the farmers were characteristically smallholders with about $50 \%$ of males and $83 \%$ of female household heads having not more than 1.50 hectares of farm. On the poverty levels of the households, it was found that the core poverty and moderate poverty lines for male, female and all households were $\$ 4078, \$ 2217$ and $\$ 3376$ and $\$ 8146, \$ 5435$ and \#6752 respectively. This implies that poverty was wide spread among the farm households especially the female headed ones. A test analysis to determine the effect of selected socioeconomic characteristics of the household heads on their levels of poverty indicates that four variables were significantly related to the household poverty levels, namely level of formal education, family size, farm size and household monthly income $(P \leq 0.05)$. A number of recommendations were made including the need for family planning among the rural households so that they produce only the number of children they can take care of to guarantee them minimum acceptable standard of living.
\end{abstract}

Key words: gender gap, poverty, households, Delta State, male headed households, female headed households

http://dx.doi.org/10.4314/jafs.v11i1.3

\section{INTRODUCTION}

Poverty involves not only the lack of the necessities of material well-being but the denial of opportunities for living a tolerable life. Life can be deprived of knowledge and communication, which can rob of dignity, confidence and self respect of man (Narayan et al, 2000).

The poor are those whose expenditure (or income) falls below a poverty line. Households whose consumption expenditure falls below this line are considered to be poor. The rural Journal of the Faculty of Agriculture and Veterinary Medicine, Imo State University Owerri website: www ajol.info 
poor especially women lack basic human capabilities and this lack denies them basic opportunities and choices. They need to be empowered to enable them develop self confidence and raise their social status in order to improve their social and economic condition. According to the Nigerian Federal Office of Statistics (1999), in 1960 about 15\% of the population was poor, but by 1980 this percentage has risen to $28 \%$. By 1996, the incidence of poverty in Nigeria was $66 \%$ or 76.6 million people. Poverty incidence is the proportion of population whose income falls below the subsistence minimum. The UN human poverty index in 1999 placed Nigerian amongst the 25 poorest nations in the world. Poverty depth shows how poor are poor and it measures average consumption/income shortfall of poor population expressed as proportion of absolute poverty line.

According to a demographic survey of the National Planning Commission (1996), female headed households constitute $23 \%$ in south east Nigeria. This empirical data implies that many Nigeria women, at least 16 million of them (Ogbonna and Okoroafor, 2004) spear head household economy in both rural and urban centres. Women who assume household headship position in Nigeria include women with handicapped husbands, widows, divorced women and unmarried mothers. Thus circumstances beyond their control force the headship of their household on them. Batie (1992) observed that women headed households bear the burden for catering for their handicapped husbands (whether physically or financially), their children and wards.

Batie (1992) further observed that women household heads subsist at the various level of deprivation. They are faced with acute shortage of production resources. They respond by intensifying and over exploiting of available natural resources since they must ensure survival of their households.

In sub-Sahara Africa, including Nigeria poverty is widespread among people with low education, unstable employment, unemployment, low status job and absence of material wealth (Ike and Uzokwe 2011). All these factors are prevalent among rural households. The situation is even worse in this part of Nigeria, especially income inequality, a clear signal of poverty which is more to the disadvantage of women farmers.

As observed by Ike (2012), there is unequal access to land tenure, education, extension services, technology and credits among gender in Delta State and this has led to inequalities in farm income and standard of living among different male and female headed households. Hence women household heads are caught in the vicious cycle of poor socioeconomic status. This work therefore sought to establish whether there is a gap or not in poverty among male and female headed households in the study area. Again, estimating and comparing the incidence, depth and severity of poverty among the gender groups was done so as to help in establishing whether or not there is a gap in poverty amongst them. These were the major challenges of this study.

Specifically the study sought to:

Journal of the Faculty of Agriculture and Veterinary Medicine, Imo State University Owerri website: www ajol.info 
- identify the socio-economic characteristics of female and male headed household in Ukwani local government area,

- measure the poverty gap between female and male headed farm families in the study area,

- determine and compare the poverty incidence, depth, and severity among male and female farming family, and

- identify and analyze the determinants, of poverty incidence among farm family head in the study area.

\section{HYPOTHESES}

This study was guided with the following hypotheses.

i. Ho: there is no significant gap between poverty levels of male and female farming heads in the study area.

ii. Ho: the selected socio-economic variables do not have economic effect in the determination of poverty among farm family heads in the study area.

\section{METHODOLOGY}

The study area is Ukwani Local Government Area of Delta state, Nigeria. It has a population of 120,390 composed of 59,162 males and 61,228 females (NPC, 2006). The area is approximately between longitude $4.45^{\circ}$ and $6.30^{\circ}$ west and latitude $5.45^{\circ}$ and $30^{\circ}$ north of the equator. The major occupation of the indigenes in the area is farming, transportation, petty trading and several non farm activities such as food processing and vocational jobs. The local government area is made up of ten communities, which includes: Akoku, Amai, Ebedei, Eziokpor, Ezionum, Obiaruku, Umukwata, Umuebu, Umuaja and Umutu.

\section{SAMPLING PROCEDURE/ DATA COLLECTION}

Simple random sampling technique was used to select seven out of the 10 communities. From each of these selected communities 10 respondents were selected from a list of farm families drawn with assistance of extension officers covering the area. This gave a total sample size of 70 respondents.

Data for this study which were from primary sources were collected with the use of oral interview and structured questionnaire. The questionnaire was used to seek information on the socioeconomic characteristics of the respondents.

\section{METHODS OF DATA ANALYSIS}

Various methods were employed in analyzing the data, including various descriptive statistical tools such as the use of tables, mean, percentages and t-test and regression inferential tool as well as poverty measure using Foster Greer and Thorbecke (1984) to estimate the incidence of poverty in the study area.

Journal of the Faculty of Agriculture and Veterinary Medicine, Imo State University Owerri website: www ajol.info 
Specifically, objective 1 was realised by means of descriptive statistics. Objective 2 was achieved using poverty index measure, while objectives 3 and 4 were achieved by means of $\mathrm{t}$-test and ordinary least square regression analysis respectively.

\section{MODEL SPECIFICATION}

The Poverty line in the area was derived from mean per capita household expenditure (MCHE) as;

$$
\text { Per capita household expenditure }=\frac{T H M E}{H S}
$$

where THME is the total household monthly expenditure ( $\#)$ and HS is the household size. The mean per capita expenditure (MPCE) for all respondents was determined as the ratio of total per capita expenditure for all households to total number of households as follows:

$$
M P C E=\frac{T P C E}{T N H},
$$

Where TPCE is total per capita expenditure for all households and

TNH is total number of households

Three mutually exclusive classes obtained from the MPCE are:

i. A core poverty line equivalent to one third of MPCE.

ii. The moderate poverty line equivalent to two third of the MPCE.

iii. The non-poor

The poverty incidence was measured using Foster Greer and Thorbecke (FGT)

(1984) approach. The FGT measure is given mathematically as follows.

$$
P_{\alpha}=\frac{1}{n} \sum_{i=1}^{q}\left[\frac{Z-Y_{i}}{Z}\right]^{\alpha}
$$

Where $\alpha \geq 0$

$\mathrm{Y}_{\mathrm{i}}=$ per capita household expenditure

$\mathrm{Z}=$ poverty line

$\mathrm{n}=$ total population

$\mathrm{q}=$ number of poor people (below poverty line)

\section{Poverty Index}

The poverty index Po has the formula

$$
P_{0}=\frac{q}{n}=H
$$

$\mathrm{P}_{\mathrm{o}}=$ Poverty Index

$\mathrm{H}=$ Head count

This measures the depth of poverty, otherwise called poverty gap between poor household and poverty line.

Journal of the Faculty of Agriculture and Veterinary Medicine, Imo State University Owerri website: www ajol.info 
if $\alpha=1$

$$
P_{i}=\frac{1}{n} \sum_{i=1}^{q}\left[\frac{Z-Y}{Z}\right]
$$

and if $\alpha=2$

$$
P=\frac{1}{n} \sum_{i=1}^{q}\left[\frac{Z-Y}{Z}\right]^{2}
$$

\section{The t-test}

The t-test was used to compare the poverty indices of men with those of women.

This is given by the formula:

$$
t_{c a l}=\frac{M_{m}-W_{m}}{\sqrt{\frac{S_{m}}{n_{m}-1}+\frac{S_{w}}{n_{w}-1}}}
$$

Where:

$\mathrm{M}_{\mathrm{m}}=$ mean of poverty incidence of male headed household

$\mathrm{W}_{\mathrm{m}}=$ mean of poverty incidence of female headed household

$\mathrm{S}_{\mathrm{m}}=$ variance for men

$\mathrm{S}_{\mathrm{w}}=$ variance for women

$\mathrm{N}_{\mathrm{m}}=$ number of subjects in men group

$\mathrm{N}_{\mathrm{w}}=$ number of subjects in women group

Ordinary Least Square Regression, commonly called OLS regression was used to analyse the determinants of poverty gap among the respondents. In the dichotomous (i.e. binary), the independent variable may be quantitative categorical or a mixture of the two. The regression analysis was carried out to determine the effect of selected socioeconomic characteristics of the household heads on their levels of poverty. This analysis was done to enable the test of hypothesis which states that the selected socioeconomic variables of the respondents do not have significant effect on their poverty levels.

The regression model is given as;

$\mathrm{PL}=\mathrm{f}\left(\mathrm{X}_{1}, \mathrm{X}_{2}, \mathrm{X}_{3}, \mathrm{X}_{4}, \mathrm{X}_{5}, \mathrm{X}_{6}, \mathrm{X}_{7}, \mathrm{X}_{8}, \varepsilon\right)$

where, $\mathrm{PL}=$ Poverty level, $\mathrm{X}_{1}=$ Gender, $\mathrm{X}_{2}=$ Age of respondents, $\mathrm{X}_{3}=$ Level of formal education, $\mathrm{X}_{4}=$ Farm size, $\mathrm{X}_{5}=$ Family size, $\mathrm{X}_{6}=$ Household Monthly income, $\mathrm{X}_{7}=$ Household Monthly savings, $\mathrm{X}_{8}=$ Farming experience, $\varepsilon=$ stochastic error term.

Three functional forms, namely linear, semi log and double log were estimated. Based on fulfillment of statistical, econometric and theoretical conditions, the best fit to the data set was adopted as the lead form, and therefore used for further analyses.

Journal of the Faculty of Agriculture and Veterinary Medicine, Imo State University Owerri website: www ajol.info 


\section{RESULTS AND DISCUSSIONS}

\section{Socio-economic characteristic of female and male headed farming households.}

The socioeconomic characteristics of the respondents are presented in Table 1.

Table 1 show that about $9 \%$ of male and $14 \%$ female respondents respectively were less than 30 years of age while majority of the farmers $(51.4 \%)$ had a family size of between 4 and 6 . Also about $40 \%$ of the entire farmers had no formal education while as many as $67.2 \%$ of the respondents had farm sizes of not more than 1.5 hectares of land.

\section{Poverty Indices}

Presented in Table 2 are the poverty indices for male and female headed as well all households. On the average, the male headed, female headed and all households have household sizes of 5, 4 and 5 respectively. The sizes appear to be evenly distributed, although the male headed households appear to be larger than the female headed ones. The implication of large family size among farm households is increased poverty. This is in line with the findings of Ike (2012) which had established a positive correlation between large family size and poverty in rural communities where farming is the mainstay of the economy. The mean per capita income and mean per capita expenditure for the male headed, female headed and all households were $\$ 16360$ and $\$ 12219, \$ 1808$ and $\$ 8153$ and $\$ 13562$ and $\$ 10128$ respectively. Again, all values for male appear to be higher than for female headed households.

Core poverty and moderate poverty lines for male, female and all households were $\$ 4078$, $\$ 2217$ and $\$ 3376$ and $\$ 8146,5435$ and 6752 respectively. The results show that with respect to the incidence of poverty, about $43 \%, 57 \%$ and $51 \%$ of male, female and all households respectively were below the poverty line. This indicates that poverty is wide spread among the farm households especially the female headed ones. Only about 25\%, $16 \%$ and $20 \%$ of the male headed, female headed and all households have household respectively were non - poor among the respondents.

The intensity of poverty (poverty gap index) was $25.13 \%, 34.82 \%$ and $28.98 \%$ for the male headed, female headed and all households household respectively. These reflect the mean of the gap between the core poor standard of living and the poverty line. They show the shortfall of the core Poor's expenditure from the poverty line expressed as the average of all in the population. This is a measure of the cost of eliminating poverty (relative to the poverty line), because it shows how much would have to be transferred to the poor to bring their incomes or expenditures up to the poverty line (as a proportion of the poverty line). The minimum cost of eliminating poverty using targeted transfers is simply the sum of all the poverty gaps in a population; every gap is filled up to the poverty line. From the result, it could be inferred that about 25\% (N1766), 35\% ( $\mathrm{N1544)}$ and 29\% ( $\mathrm{N1711)}$ are needed to bring their incomes or

Journal of the Faculty of Agriculture and Veterinary Medicine, Imo State University Owerri website: www ajol.info 
expenditures of the male headed, female headed and all households up to the poverty line respectively.

The squared poverty gaps (poverty severity/depth) were $6.32 \%, 12.12 \%$ and $8.40 \%$ for male headed, female headed and all households respectively. This shows there is more inequality of standard of living among the female headed than the male headed households. This means that poverty tends to be more severe among female headed than the male headed households.

The $\mathrm{t}$ - test for differences in poverty indicators between female headed and the male headed households are presented in Table 3 . The results show that while household size and depth of poverty are significantly the same between the two groups at $\mathrm{P}(\leq 0.05)$, the household monthly income, total household monthly expenditure, mean per capita household expenditure, mean per capita household income and intensity of poverty appear to be significantly different between the two groups. The male headed households had higher values for household monthly income, total household monthly expenditure, mean per capita household expenditure and mean per capita household income, but lower values for intensity of poverty than female households respectively. These imply overall higher living standards among male headed households than those of female headed households.

\section{Socioeconomic characteristics affecting poverty levels of households}

A regression analysis was carried out to determine the effect of selected socioeconomic characteristics of the household heads on their levels of poverty. This analysis was done to enable the test of hypothesis which states that the selected socioeconomic variables of the respondents do not have significant effect on their poverty levels. The result is presented in Table 4. Three functional forms were tested, namely linear, semi log and double log functions. The linear functional form with the highest number of significant variables and adjusted $\mathrm{R}$ was chosen as the lead equation and therefore presented in the table as well as used for further discussion.

The significant variables were level of formal education, family size, farm size and household monthly income. The coefficients of these variables had signs which were in consonance with a priori expectations. So, with the exception of household/family size the coefficients of other three variables were positive.

The household/family size with negative coefficient implies that families with large household sizes had higher poverty incidence than those with smaller sizes. This is because, with fixed income, the resources of the household are stretched over a large number of people. Family planning could be a way out for people to improve their standards of living. Alternatively, diversification of the income bases of the household could enable them generate sufficient incomes to cater for their needs.

Farm size which had positive coefficient signifies that with larger farm sizes, families could generate more income to cater for their needs. However, with the limited income of the Journal of the Faculty of Agriculture and Veterinary Medicine, Imo State University Owerri website: www ajol.info 
farmers, their ability to cultivate farms of large sizes is limited. To do so require mechanization and this is beyond the capacity of the farmers. Financial assistance in the form of affordable credit facilities and the liberalisation of tractor hiring services are required.

The household income has direct bearing on their level of wellbeing as well as poverty. Any measure aimed at increasing the household income such as access to production credit, ease of access to land for increased farm size, input subsidy and timely supply, provision of storage facilities will bail the farm households out of poverty.

Education no doubt is a panacea to more income opportunities. With education, farmers are able to manage their resources better as well as adopt better techniques of production. This includes ability to combine factors of production more efficiently leading to input utilization at least cost levels. To bring about improved education for farmers, particularly those without formal education, on farm adult literacy programme should be mounted for farmers at little or no cost on their part.

Other variables considered, though not significantly related to poverty levels of the households were age, gender, monthly savings, farming experience of household heads.

\section{CONCLUSION AND RECOMMENDATIONS}

The study which focused on the estimation of poverty gap between female and male headed farm families in Ukwani local government area of Delta State showed that the farmers were characteristically smallholders with about $50 \%$ of males and $83 \%$ of female household heads having not more than 1.50 hectares of farm. It was found that poverty was wide spread among the farm households especially the female headed ones. It was further found that four variables were significantly related to the household poverty levels namely level of formal education, family size, farm size and household monthly income.

Arising from findings of the study, the following recommendations were made:

i. The primary health unit at the various local government areas as well as State ministries of health should intensify the campaign on family planning among the rural households so that they produce only the number of children they can take care of to guarantee them minimum acceptable standard of living.

ii. Although majority of the respondents indicated their desirability for credit, only a few have had access to such facility. It is therefore recommended that deliberate policy should be put in place to guarantee them easier and affordable access to production credit. Among such policy is that which will encourage the formation of cooperative societies amongst them. In addition, governments should grant the farmers input subsidy and ensure timely supply of such inputs and provision of storage facilities so as to bail them out of poverty.

Journal of the Faculty of Agriculture and Veterinary Medicine, Imo State University Owerri website: www ajol.info 


\section{REFERENCES}

Batie S.S (1992): Sustainable development concepts and strategies in sustainable agricultural development the role of international cooperation "proceeding of the $21^{\text {st }}$ international conference on agricultural economics held in Japan 22-29 August.

Federal office of statistics (1999): poverty profile for Nigeria: 1980-1996.

Foster J. Greer J. and E. Thorbecke (1984): A class decomposable poverty measure Economical vpl.52 page 529-547.

Ike, P.C. (2012), "Gender Dimensions of Poverty among Rural Farm Households in Delta State, Nigeria", Agricultura Tropicet Subtropica 45(1), Pp 13 - 20

Ike, P.C. and U.N. Uzokwe (2011), "Estimation of Poverty among Rural Farming

Households in Delta State, Nigeria", International Journal of Agriculture and Food Science Technology, 2 (1), 11-21

Narayam, D.R. Chambers K.M Shah and P. Petesch (2000): voices of the poor; crying out for change. New York. Oxford university press for the World Bank pp21-36

Ogbonna K.I and Okoroafor (2004): Enhancing the capacity of women for increased participation in Nigeria main stream a research designing of strategies in Faman journal volume 7, No.2 pg 36-38.

UNDP (United Nations development programme) (1998): Human Development Report, Lagos. United Nations

World Bank (1996): Nigeria: Targeting communities for effective poverty alleviation. African region, Number 68

World Bank (1996): Nigeria poverty in the midst of plenty the challenge of growth with inclusion. World Bank poverty Assessment Report No 14733 UN May 31 population and human Resource Division Western African Department African region.

World Bank (1999): Gender, Growth, Growth and poverty Reduction: split status report of poverty in sub-Sahara Africa SSA, 1998 Washington D.C pp ixiii.

Journal of the Faculty of Agriculture and Veterinary Medicine, Imo State University Owerri website: www ajol.info 


\section{APPENDIX}

Table 1: Socioeconomic Characteristics of Female and Male Headed Households

\begin{tabular}{|c|c|c|c|}
\hline Age range & Male & Female & All farmers \\
\hline$\leq 30$ years & $3(8.8)$ & $5(13.9)$ & $8(11.4)$ \\
\hline $31-40$ years & $10(29.4)$ & $9(25.0)$ & $19(27.1)$ \\
\hline $41-50$ & $7(20.6)$ & $14(38.9)$ & $21(30.0)$ \\
\hline$>50$ year & $14(41.2)$ & $8(22.9)$ & $22(31.4)$ \\
\hline Household size & Male & Female & All farmers \\
\hline$\leq 3$ & $8(23.5)$ & $8(22.2)$ & $16(22.9)$ \\
\hline $4-6$ & $13(38.2)$ & $23(63.9)$ & $36(51.4)$ \\
\hline $7-10$ & $9(26.5)$ & $1(2.8)$ & $10(14.3)$ \\
\hline$>10$ & $4(11.8)$ & $4(11.1)$ & $8(11.4)$ \\
\hline Marital status & Male & Female & All farmers \\
\hline Single & $4(11.8)$ & $4(11.1)$ & $8(11.4)$ \\
\hline Married & $24(70.6)$ & $22(61.1)$ & $4(65.7)$ \\
\hline Divorced & $2(5.9)$ & $3(8.3)$ & $5(7.1)$ \\
\hline Widow/Widower & $4(11.8)$ & $7(19.4)$ & $11(15.7)$ \\
\hline Educational level & Male & Female & All farmers \\
\hline No formal Education & $13(38.2)$ & $15(41.7)$ & $28(40.0)$ \\
\hline Primary Education & $16(47.1)$ & $12(33.3)$ & $28(40.0)$ \\
\hline Secondary Education & $2(5.9)$ & $4(11.1)$ & $6(8.6)$ \\
\hline NCE/HND & $3(8.8)$ & $4(11.1)$ & $7(10.0)$ \\
\hline First and Higher Degree & $0(0)$ & $1(2.8)$ & $1(1.4)$ \\
\hline Type of enterprise & Male & Female & Total \\
\hline Arable Crop Farming & $29(41.4)$ & $35(97.2)$ & $64(91.4)$ \\
\hline Tree Crops Farming & $2(5.9)$ & $0(0)$ & $2(2.9)$ \\
\hline Mixed Farming & $3(8.8)$ & $1(2.8)$ & $4(5.7)$ \\
\hline Non farm income activities & Male & Female & All farmers \\
\hline Civil service & $26(76.5)$ & $30(83.3)$ & $56(80.0)$ \\
\hline Artisan/Fashion services & $4(11.8)$ & $4(11.1)$ & $8(11.4)$ \\
\hline Trading and transport services & $2(5.9)$ & $0(0)$ & $2(2.9)$ \\
\hline Grading /Agro services & $2(5.9)$ & $2(5.6)$ & $4(5.7)$ \\
\hline Methods of land acquisition & Male & Female & Total \\
\hline Individual ownership/ inheritance & $9(26.5)$ & $7(19.4)$ & $16(22.9)$ \\
\hline Community Ownership & $20(25.8)$ & $23(63.9)$ & $43(61.4)$ \\
\hline Rented/purchase & $5(14.7)$ & $6(16.7)$ & $11(15.7)$ \\
\hline Farm size & Male & Female & Total \\
\hline$\leq 1.00 \mathrm{ha}$ & $0(0)$ & $3(8.3)$ & $3(4.3)$ \\
\hline $1.10-1.50 \mathrm{ha}$ & $17(50.0)$ & $27(75.0)$ & $44(62.9)$ \\
\hline$>1.50$ ha & $11(32.4)$ & $2(5.6)$ & $13(18.6)$ \\
\hline Farming Experience & Male & Female & Total \\
\hline Less or equal to 10 years & $1(2.9)$ & $2(5.6)$ & $3(4.3)$ \\
\hline $11-15$ years & $7(20.6)$ & $7(19.4)$ & $14(20.0)$ \\
\hline $16-20$ years & $9(26.5)$ & $5(13.9)$ & $14(20.0)$ \\
\hline 21 - 30 years & $5(14.7)$ & $6(16.7)$ & $11(15.7)$ \\
\hline
\end{tabular}

Note: Figures in parentheses are percentage of column total 
Table 2: Poverty Indices by Male and Female - headed households

\begin{tabular}{lrrr}
\hline \multicolumn{1}{c}{ Poverty Indices } & $\begin{array}{c}\text { Male Headed } \\
\text { Household }\end{array}$ & $\begin{array}{c}\text { Female } \\
\text { Headed } \\
\text { Household }\end{array}$ & $\begin{array}{c}\text { All } \\
\text { Households }\end{array}$ \\
Number of Households & 34 & 36 & 70 \\
Mean Household size & 5.29 & 4.94 & 5.11 \\
Mean Per capita Income (N) & 16360 & 11808 & 13562 \\
Mean per Capita Expenditure (N) & 12219 & 8153 & 10128 \\
Core Poverty Line (N) (\%) & $4078(43.30)$ & $2718(56.80)$ & $3376(50.67)$ \\
Moderate Poverty Line (N) (\%) & $8146(31.70)$ & $5435(27.01)$ & $6752(29.11)$ \\
Non-Poor (N) (\%) & $\geq 8146$ & $\geq 5435$ & $\geq 6752$ \\
& $(25.00)$ & $(16.19)$ & $(20.22)$ \\
Poverty incidence (\%) & 43.30 & 56.80 & 50.67 \\
Intensity (Gap) of Poverty (\%) & 25.13 & 34.82 & 28.98 \\
Depth (Severity) of Poverty (\%) & 6.32 & 12.12 & 8.40 \\
\hline
\end{tabular}

Note: Figures in parentheses are percentages of column number of household.

Table 3: Comparison of Poverty Indices between Male and Female headed Households

\begin{tabular}{|c|c|c|c|c|c|c|c|}
\hline & $\begin{array}{r}\text { Mea } \\
\text { variab } \\
\text { Gen } \\
\end{array}$ & $\begin{array}{l}\text { s of } \\
\text { es by } \\
\text { der }\end{array}$ & $\begin{array}{c}\text { Mean } \\
\text { Difference }\end{array}$ & $\begin{array}{c}\text { Standard } \\
\text { Error of } \\
\text { Difference }\end{array}$ & $\begin{array}{l}\text { Degree } \\
\text { of } \\
\text { freedom }\end{array}$ & $\begin{array}{c}\mathrm{t}- \\
\text { Value }\end{array}$ & $\begin{array}{c}\text { Level of } \\
\text { Significance }\end{array}$ \\
\hline \multirow[b]{2}{*}{$\begin{array}{l}\text { Household } \\
\text { monthly income }\end{array}$} & Male & 31568 & \multirow[b]{2}{*}{10922} & \multirow[b]{2}{*}{4150.05} & \multirow[b]{2}{*}{68.00} & \multirow[b]{2}{*}{2.63} & \multirow[b]{2}{*}{$* *$} \\
\hline & Female & 20646 & & & & & \\
\hline \multirow{2}{*}{ Household size } & Male & 5.29 & \multirow{2}{*}{0.35} & \multirow{2}{*}{0.38} & \multirow{2}{*}{68.00} & \multirow{2}{*}{0.92} & \multirow{2}{*}{ NS } \\
\hline & Female & 4.94 & & & & & \\
\hline \multirow{2}{*}{$\begin{array}{l}\text { Total household } \\
\text { monthly } \\
\text { expenditure }\end{array}$} & Male & 61549 & \multirow{2}{*}{26484} & \multirow{2}{*}{10741.03} & \multirow{2}{*}{68.00} & \multirow{2}{*}{2.47} & \multirow{2}{*}{$*$} \\
\hline & Female & 35065 & & & & & \\
\hline \multirow{2}{*}{$\begin{array}{l}\text { Mean per capita } \\
\text { household } \\
\text { expenditure }\end{array}$} & Male & 12219 & \multirow{2}{*}{4066} & \multirow{2}{*}{1206.84} & \multirow{2}{*}{68.00} & \multirow{2}{*}{3.37} & \multirow{2}{*}{$* *$} \\
\hline & Female & 8153 & & & & & \\
\hline \multirow{2}{*}{$\begin{array}{l}\text { Mean per capita } \\
\text { household } \\
\text { income }\end{array}$} & Male & 6360 & \multirow{2}{*}{1552} & \multirow{2}{*}{545.78} & \multirow{2}{*}{68.00} & \multirow{2}{*}{2.84} & \multirow{2}{*}{$* *$} \\
\hline & Female & 4808 & & & & & \\
\hline \multirow{2}{*}{$\begin{array}{l}\text { Intensity of } \\
\text { poverty }\end{array}$} & Male & 25.13 & \multirow{2}{*}{-9.69} & \multirow{2}{*}{-4.35} & \multirow{2}{*}{68.00} & \multirow{2}{*}{2.23} & \multirow{2}{*}{$*$} \\
\hline & Female & 34.82 & & & & & \\
\hline \multirow{2}{*}{ Dept of poverty } & Male & 6.32 & \multirow{2}{*}{-5.8} & & & & \\
\hline & Female & 12.12 & & $-0.6 /$ & 08.00 & 0.81 & NS \\
\hline
\end{tabular}

Note: $*=$ Significant at $\mathrm{P}(\leq 0.01), * *=$ Significant at $\mathrm{P}(\leq 0.05)$ and $\mathrm{NS}=$ Not significant at $\mathrm{P}(>0.05)$

Journal of the Faculty of Agriculture and Veterinary Medicine, Imo State University Owerri website: www ajol.info 
Table 4: Linear Regression analysis to determine the factors that influence the poverty incidence on the households

\begin{tabular}{|c|c|c|c|c|c|}
\hline & Coefficients & $\begin{array}{c}\text { Standard } \\
\text { Error }\end{array}$ & t Stat & P-value & \\
\hline Intercept & 9.4790 & 1.4844 & 6.3859 & $2.6 \mathrm{E}-08$ & $* *$ \\
\hline Gender & 0.1011 & 0.4463 & 0.2265 & 0.821579 & \\
\hline Age of respondents & 0.0068 & 0.0266 & 0.2561 & 0.798744 & \\
\hline Level of formal education & 0.0919 & 0.0355 & 2.5841 & 0.039887 & $*$ \\
\hline Farm size & 0.6970 & 0.3358 & 2.0755 & 0.049694 & $*$ \\
\hline Family size & -0.3116 & 0.1193 & -2.6122 & 0.011312 & $*$ \\
\hline Household Monthly income & 0.0004 & 0.0000 & 8.6572 & $3.28 \mathrm{E}-12$ & $* *$ \\
\hline Household Monthly savings & 0.0017 & 0.0016 & 1.1085 & 0.06714 & \\
\hline Farming experience & 0.0155 & 0.0368 & 0.4224 & 0.674243 & \\
\hline F Calculated & 12.952 & & & & \\
\hline $\mathrm{R}^{2}$ & 0.629 & & & & \\
\hline Adjusted $\mathrm{R}^{2}$ & 0.581 & & & & \\
\hline
\end{tabular}

Note: * and **imply significant at $\mathrm{P} \leq 0.05$ and 0.01 respectively 